References:

1. Vitenko I. S., Borysyuk A. S., Vitenko T. I. (2009) Osnovy psykhologiyi. Osnovy pedagogiky: navch.-metod. posibnyk [Fundamentals of psychology]. Chernivci: Knygy - XXI, 200 s. [in Ukrainian]

2. Volnova L. (2020) Chynnyky vynyknennya ta posylennya proyaviv tryvogy u ditej doshkilnogo viku [Factors of occurrence and intensification of anxiety in preschool children]. Naukovyj chasopys NPU imeni M. P. Dragomanova, № 9 (54). S. 33, DOI: https://doi.org/10.31392/NPU-nc.series12.2020.9(54).03 (data zvernennya: 28.06.2020).

3. Kornyenko S. Khymyya emocyj [Chemistry of emotions]. URL : http://ethology.ru/library/?id=287 (data zvernennya: 15.06.2020).

4. Litvyakova I. A., Khaneczka N. V. (2017) Doslidzhennya vplyvu emocij na stan osobystosti. Molodyj vchenyj [Study of the influence of emotions on the state of personality]. № 11. S. 806-809 URL : http://molodyvcheny.in.ua/files/journal/2017/11/195. pdf (data zvernennya: 21.05.2020).

5. Motruk T. O. (2011). Emocijni stany osobystosti yak psykhologichnyj fenomen [Emotional states of personality as a psychological phenomenon]. Visnyk Kharkivskogo nacionalnogo universytetu imeni V. N. Karazina. Seriya: Psykhologiya. 2011. № 937, vyp. 45. S. 202-205. [in Ukrainian]

6. Tlumachnyj slovnyk (2007) [Explanatory dictionary] V. V. Synyavskyj ta in.; za red. N. A. Pobirchenko. Kyiv: Nauk. svit. 274 s. URL: http://elibrary.kubg.edu.ua/id/eprint/5980/3/O_Serhieienkova_IL.pdf?fbclid=IwAR1WPmLSgT0KXLJd2XYKNrMSjH12OuokFEwmOmLaV0IA-Cbmh95h6YfFd4 (data zvernennya: 18.06..2020).

\title{
Smola O. V. Characteristics of the emotional state of children with mental disorders in preschool institutions
}

The article analyzes the features of the emotional state of children with mental disorders. The following phenomena are considered in this scientific work: manifestations of aggressive and autoaggressive behavior, children's anxiety, stability of emotional states in children with different nosologies. The article highlights the features of emotional states and emotions, their differences and their relationship, namely: emotional states are a type of mental state, are long-lasting and based on emotions. Emotions are the mental response to information, stimuli, situations, they are closely related to the psychophysical characteristics of the individual. The structure of emotions, their nature and connection with neurotransmitters are revealed. Mental disorders affect the emotional sphere, changing the process of perception of the world, response to it and the ability to adapt. Children with these disorders have difficulties in communication, learning, it is more difficult for them to go through the process of socialization.

The article presents the results of a study aimed at analyzing emotional states in children with mental disorders and identifying signs of aggression and anxiety. In order to increase the informativeness of the study, certain methods of scientific research were used: analysis of scientific publications on this topic, questionnaires. The respondents of this questionnaire were psychologists of the municipal preschool educational institution "Child Development Center "I + family". and parents of children with mental disorders. Methods and techniques of work of psychologists with child aggression, anxiety are analyzed. In the scientific work, another area of research was to identify the correlation between the level of anxiety and aggression in children and their nosologies. The issue of parents' competence in working with children, their aggressive and disturbing manifestations has been studied. It was found that most of the interviewed parents who have children with mental disorders consider aggression an undesirable condition and have a fairly low level of competence. It was also found that almost all parents should be willing to improve their knowledge and skills on this topic.

Key words: aggression, behavior, children, emotional state, feature, mental disorders, nosologies.

УДК 811.161.2243:378.016

DOI https://doi.org/10.31392/NPU-nc.series5.2020.75.41

Стефанишин К. Л., Тишковець М. П.

\section{НАВЧАЛЬНО-МЕТОДИЧНЕ ЗАБЕЗПЕЧЕННЯ ДО ВИВЧЕННЯ ТЕМИ “МІСЯЦІ. ПОРИ РОКУ” НА ЗАНЯТТЯХ З УКРАЇНСЬКОЇ МОВИ ЯК ІНОЗЕМНОЇ}

Стаття стосується проблеми навчально-методичного забезпечення прочесу навчання української мови як іноземної. Основною формою навчальної діяльності студентів у медичних закладах вищої освіти із дисиипліни "Українська мова як іноземна" с практичне заняття. Практичні заняття у 3 ВО передбачають детальний розгляд студентами окремих теоретичних положень навчальної дисиипліни з викладачем і формування вміння та навичок їх практичного застосування шляхом індивідуального виконання студентом сформульованих завдань і вирімення ситуаційних задач. Представлено методичну розробку практичного заняття з украӥнської мови як іноземної “Місяці. Пори року” для викладачів закладів вищої освіти.

Хід заняття структуровано згідно з вимогами до практичних занять у вищій школі й адаптовано до комунікативних потреб чужсземних студентів, які навчаються в Україні. Структура заняття містить пять етапів: організаційну частину, засвоєння лексико-граматичного матеріалу до теми, виконання тренувальних вправ, роботу з текстом, поточний контроль. Змістове наповнення відповідає програмі навчальної дисципліни "Украӥнська мова як іноземна", завдання побудовано з урахуванням програмних вимог і підпорядковано меті дисципліни - забезпеченню базових комунікативних потреб чужоземних студентів у побутовій і навчально-професійній сферах. Розроблена система вправ призначена для формування та розвитку різних видів мовленнєвої діяльності (слухання, говоріння, читання та письма). Знання лексики на позначення місяиів і пір року, засвоєння порядкових числівників і правил їх уживання у мовленні, відповідь на запитання КОЛИ? з використанням назв місяців і пір року, вдосконалення навичок читання тексту в межах актуальної теми дозволяють забезпечити реалізацію комунікативних потреб іноземних студентів у різних сферах спілкування: побутовій, сочіально-культурній, офіційно-діловій, навчально-професійній.

Ключові слова: українська мова як іноземна, методична розробка, знання, вміння, комунікативний підхід, завдання, місяиі, пори року. 
Основним засобом навчання, як відомо, є підручник - орієнтир логічного розгортання процесу навчання відповідно до мети та змісту освітнього процесу для педагога і джерело знань та інструмент засвоєння для студента. Сучасний підручник виконує освітню, розвивальну, виховну, дослідницьку функції, зумовлені системою дидактичних принципів науковості, доступності, цілеспрямованості, систематичності та послідовності, зв’язку iз життям тощо. Ураховуючи досвід колективу кафедри української мови Тернопільського національного медичного університету імені І. Я. Горбачевського, зауважимо, що одного підручника недостатньо для реалізації мети навчання української мови як іноземної - вільного спілкування нею у реальних, життєво важливих ситуаціях. Потрібно створювати навчально-методичний комплекс із дисциплін кафедри, до якого мають входити матеріали до практичних занять для студентів, методичні вказівки для студентів і методичні розробки для викладачів, відеоматеріали до заняття, набори тестів і завдань для поточного і підсумкового оцінювання знань студентів тощо.

Згідно з навчальним планом підготовки здобувачів вищої освіти другого (магістерського) або першого (бакалаврського) рівня відповідних кваліфікацій і спеціальностей у закладах вищої освіти МОЗ України формами навчального процесу з дисципліни “Українська мова як іноземна” є: практичні заняття, самостійна робота студентів, консультації [1]. Практичні заняття передбачають детальний розгляд студентами окремих теоретичних положень навчальної дисципліни з викладачем і формування вміння та навичок їх практичного застосування шляхом індивідуального виконання студентом сформульованих завдань і вирішення ситуаційних задач. 3 огляду на кількість годин, відведених навчальним планом на кожну із форм навчального процесу з української мови як іноземної, практичне заняття є основною формою навчальної діяльності студентів.

Мета статті - запропонувати методичну розробку для викладача до теми “Місяці. Пори року”, апробовану на практичних заняттях з української мови як іноземної авторами цієї праці.

Методична розробка укладена з урахуванням програмових вимог для підготовки англомовних студентів у ЗВО МОЗ України і включає практичний матеріал, який є змістовою частиною програми для студентів другого курсу галузі знань 22 “Охорона здоров’я” [1].

Тема заняття. Місяці. Пори року.

Мета: ознайомити студентів із лексичною базою на позначення місяців і пір року; засвоїти порядкові числівники та розвивати вміння уживати їх у мовленні; вдосконалювати навички читання тексту в межах актуальної теми.

Студент повинен знати:

1. Лексичну базу на позначення місяців і пір року.

2. Порядкові числівники та правила їх уживання у мовленні.

3. Відповідь на запитання КОЛИ? з використанням назв місяців і пір року.

Студент повинен вміти:

1. Використовувати лексику на позначення місяців і пір року.

2. Правильно вживати порядкові числівники у мовленні.

3. Відповідати на запитання КОЛИ?, вживаючи назви місяців і пір року.

4. Читати текст у межах актуальної теми та відповідати на запитання до нього.

Перелік основних питань, які розглядаються на занятті:

1. Лексика на позначення місяців і пір року.

2. Порядкові числівники.

3. Відповідь на запитання КОЛИ? з уживанням назв місяців і пір року.

4. Робота з текстом.

Методика виконання практичної роботи.

Робота 1. Засвосння лексико-граматичного матеріалу до теми.

Завдання 1. Прочитайте. Запишіть. Запам'ятайте.

\begin{tabular}{|c|c|c|c|}
\hline Пори року & Коли? & Місяці & Коли? \\
\hline зима & взимку & $\begin{array}{c}\text { грудень } \\
\text { січень } \\
\text { лютий }\end{array}$ & $\begin{array}{c}\mathbf{y} \text { грудні } \\
\mathbf{y ~ с і ч н і ~} \\
\mathbf{y} \text { лютому }\end{array}$ \\
\hline весна & навесн $i$ & $\begin{array}{c}\text { березень } \\
\text { квітень } \\
\text { травень } \\
\end{array}$ & $\begin{array}{c}\text { y березні } \\
\mathbf{y} \text { квітні } \\
\mathbf{y} \text { травні }\end{array}$ \\
\hline літо & влітку & $\begin{array}{c}\text { червень } \\
\text { липень } \\
\text { серпень } \\
\end{array}$ & $\begin{array}{c}\text { y червні } \\
\text { у липні } \\
\text { у серпні }\end{array}$ \\
\hline осінь & восен $и$ & $\begin{array}{c}\text { вересень } \\
\text { жовтень } \\
\text { листопад }\end{array}$ & $\begin{array}{c}\text { у вересні } \\
\text { у жовтні } \\
\text { у листопаді }\end{array}$ \\
\hline
\end{tabular}

Завдання 2. Дайте відповіді на запитання.

1. Яка пора року зараз? 2. Яку пору року Ви любите? Чому? 3. Який зараз місяць? 4. Який місяць був раніше? 5. Який місяць буде потім? 6. Скільки місяців у кожній порі року? 7. Які Ви знаєте зимові місяці? 
8. Які Ви знаєте весняні місяці? 9. Які Ви знаєте літні місяці? 10. Які Ви знаєте осінні місяці? 11. Коли починається зима? 12. Коли починається весна? 13. Коли починається літо? 14. Коли починається осінь?

Робота 2. Виконання тренувальних вправ.

Завдання 1. Розгляньте малюнки. Яку пору року зображено на кожному з них? Поясніть, чому Ви так думаєте (малюнки додаються).

Завдання 2. Поставте запитання за зразком.

Зразок: - У вересні починається навчальний рік в університеті. - Коли починається навчальний рік в університеті?

1. У червні закінчується навчальний рік в університеті. 2. У грудні студенти складають іспити за перший семестр. 3. У січні у студентів зимові канікули. 4. У травні закінчуються заняття другого семестру. 5 . У липні студенти-іноземці їдуть додому. 6. У лютому відбудеться зустріч іноземних студентів із ректором університету. 7. У березні починається весна. 8. У серпні ми приїхали в Тернопіль. 9. У жовтні ми святкуємо День студента. 10. У листопаді день народження мого друга. 11. Восени ми познайомилися зі своїм деканом. 12. Навесні у Тернополі дуже гарно. 13. Влітку у студентів два місяці канікул. 14. Взимку ми поїдемо на екскурсію до Львова.

Завдання 3. Заповніть таблицю. Запам’ятайте порядкові числівники.

\begin{tabular}{|c|c|c|c|c|}
\hline & Чоловічий рід & Жіночий рід & Середній рід & Множина \\
\hline & Котрий? & Котра? & Котре? & Котрі? \\
\hline 1 & перший & перша & перше & перші \\
\hline 2 & другий & & друге & \\
\hline 3 & третій & третя & трет $\boldsymbol{\epsilon}$ & треті \\
\hline 4 & четвертий & четверта & & \\
\hline 5 & & пята & & \\
\hline 6 & шостий & & шосте & \\
\hline 7 & сьомий & & & сьомі \\
\hline 8 & восьмий & & & \\
\hline 9 & & & дев'яте & \\
\hline \multicolumn{5}{|l|}{10} \\
\hline 11 & одинадцятий & одинадцята & одинадцяте & одинадцяті \\
\hline 12 & дванадцятий & & & \\
\hline 13 & & тринадцята & & \\
\hline 14 & & & чотирнадцяте & \\
\hline 15 & & & & п’ятнадцяті \\
\hline 16 & шістнадцятий & & & \\
\hline \multicolumn{5}{|l|}{17} \\
\hline \multicolumn{5}{|l|}{18} \\
\hline 19 & дев'ятнадцятий & & & \\
\hline 20 & двадцятий & двадцята & двадцяте & двадцяті \\
\hline 21 & двадцять перший & двадцять перша & двадцять перше & двадцять перші \\
\hline 22 & двадцять другий & & & \\
\hline \multicolumn{5}{|l|}{23} \\
\hline 40 & сороковий & сорокова & сорокове & сорокові \\
\hline 90 & дев'яностий & дев'яноста & дев'яносте & дев'яності \\
\hline 100 & сотий & сота & соте & соті \\
\hline 1000 & тисячний & тисячна & тисячне & тисячні \\
\hline
\end{tabular}

Завдання 4. Доповніть речення.

Зразок: Жовтень - це десятий місяць року.

1. Березень - це ... місяць року. 2. Листопад - це ... місяць року. 3. Липень - це ... місяць року. 4. Січень - це ... місяць року. 5. Червень - це ... місяць року. 6. Квітень - це ... місяць року. 7. Вересень це ... місяць року. 8. Грудень - це ... місяць року. 9. Лютий - це ... місяць року. 10. Травень - це ... місяць року. 11. Серпень - це ... місяць року.

Робота 3. Робота 3 текстом.

Завдання 1. Прочитайте текст.

Навчальний рік у Тернопільському національному медичному університеті імені Івана Яковича Горбачевського починається першого вересня. Він триває десять місяців і поділяється на два семестри. Зазвичай у студентів є три заняття на день. Перше і третє - практичні, а друге заняття - це лекція.

Студенти першого курсу вивчають філософію, латинську мову і медичну термінологію, історію України й українську культуру, анатомію людини, гістологію, історію медицини. Студенти другого курсу продовжують вивчати анатомію людини, а також вчать медичну інформатику, фізіологію, гістологію, цитологію та ембріологію. 
Важливий предмет - українська мова, де студенти-іноземці вчаться говорити, читати та писати українською мовою. Спочатку їм дуже складно, але наприкінці першого курсу вони вже добре розуміють українську мову і вміють спілкуватися нею.

У грудні студенти складають іспити. Потім у них зимові канікули, які тривають два тижні. Другий семестр починається в січні і закінчується в червні. Наприкінці червня студенти складають іспити за другий семестр. Потім у них літні канікули, які тривають два місяці. Усі студенти дуже люблять цю пору року, тому що можуть поїхати до своєї сім’ї, до рідної країни.

Завдання 2. Відповідайте на запитання.

1. Коли починається навчання в університеті? 2. Скільки часу триває навчальний рік? 3. Скільки занять на день мають студенти? 4. Які це заняття? 5. Які предмети вивчають студенти першого курсу? 6. Які предмети вивчають студенти другого курсу? 7. Що роблять студенти на заняттях з української мови? 8. Коли закінчується перший семестр? 9. Коли студенти складають іспити? 10. Коли у них зимові канікули? 11. Скільки тривають зимові канікули? 12. Коли починається другий семестр? 13. Коли закінчується другий семестр? 14. Чому студенти люблять літо?

Завдання 3. Випишіть із тексту словосполучення з числівниками.

Зразок: периого вересня.

Робота 4. Поточний контроль (передбачає стандартизований метод контролю знань - письмове тестування. Студентам пропонується 12 тестових завдань (2-4 варіанти) з вибором однієї правильної відповіді. Наводимо деякі з них:

1. Оберіть правильний варіант.

А. весна: березень, квітень, червень

В. літо: червень, липень, серпень

C. осінь: вересень, жовтень, грудень

D. зима: грудень, січень, травень

Е. весна: грудень, квітень, травень

2. Закінчіть речення "Навчальний рік в університеті починається ...".

А. вересень

В. вересня

C. вересні

D. у вересні

Е. вересню

3. Закінчіть речення “Іспити за перший семестр студенти складають ...”.

А. у грудні

В. груденя

С. грудень

D. груднем

Е. грудню

4. Закінчіть речення "Навчальний рік в університеті закінчується ...".

А. червеня

B. у червні

C. червень

D. червня

Е. червню

5. Вставте пропущене слово у речення "Січень - це ... місяць року”.

А. перший

В. другий

C. третій

D. четвертий

E. п'ятий

6. Вставте пропущене слово у речення "Вересень - це ... місяць року".

А. шостий

В. сьомий

С. восьмий

D. дев'ятий

Е. десятий

Організаційна структура заняття.

1.1. Організаційна частина -5 хв.

1.2. Інструктаж студентів і розподіл груп для практичної роботи -5 хв.

1.3. Практична робота студентів - 20 хв.

1.4. Семінарське обговорення теоретичних питань і практичної роботи -40 хв.

1.5. Перевірка вихідного рівня знань (проводиться у вигляді тестування з кожної теми, розв'язування ситуаційних задач, відповідей на контрольні питання) - 20 хв. 
Технічні засоби та матеріальне забезпечення заняття: підручники, посібники, словники, довідкова література, комп'ютери, відеосистема, мольберти.

Розроблена система вправ призначена для формування та розвитку різних видів мовленнєвої діяльності (слухання, говоріння, читання та письма). Знання лексики на позначення місяців і пір року, засвоєння порядкових числівників і правила їх уживання у мовленні, відповідь на запитання КОЛИ? з використанням назв місяців і пір року, вдосконалення навичок читання тексту в межах актуальної теми дозволяють забезпечити реалізацію комунікативних потреб іноземних студентів у різних сферах спілкування: побутовій, соціальнокультурній, офіційно-діловій, навчально-професійній.

\section{Використана література:}

1. Українська мова як іноземна (англійськомовна форма навчання) : типова програма нормативної навчальної дисципліни для іноземних студентів вищих навчальних закладів МОЗ України. Галузь знань: 22 “Охорона здоров'я” / уклад. : С. М. Луцак та ін. Київ, 2016. 202 с.

2. Українська мова як іноземна : навчальний посібник / І. І. Гаврищак та ін. ; за ред. М. П. Тишковець. Тернопіль : ТДМУ, 2018. $168 \mathrm{c}$.

\section{Referenses:}

1. Ukrainska mova jak inozemna (anglijskomovna forma navchannja) : typova programa normatyvnoi navchalnoi dyscypliny dlja inozemnyh studentiv vyshhyh navchalnyh zakladiv MOZ Ukrainy. Galuz znan: 22 "Ohorona zdorovja" [Ukrainian as a foreign language (English form of teaching): typical curriculum of the normative educational discipline for foreign students] / uklad.: S. M. Lucak ta in. Kyiv, 2016. 202 p. [in Ukrainian].

2. Ukrainska mova jak inozemna: navchalnyj posibnyk [Ukrainian as a foreign language: tutorial] / I. I.Gavryshhak ta in.; za red. M. P. Tyshkovec. Ternopil : TDMU, 2018. 168 p. [in Ukrainian].

Stefanyshyn K. L., Tyshkovets M. P. Teaching and learning materials for the study of the topic "Seasons and Month" during the classes of Ukrainian as a foreign language

The article deals with the problem of educational and methodological support of the teaching process for the subject "Ukrainian as a foreign language". The main form of students educational activity at the higher medical institutions for this subject is a practical. The practicals at the higher schools provide detailed analysis of some theoretical provisions of the subject by a teacher and students, the formation of skills and abilities of their practical application by individual performance of student-formulated tasks and solving situational problems. It has been presented the methodical guidance of a practical class on the Ukrainian language as a foreign language "Months. Seasons of the year" for the teachers of higher schools.

The course is structured according to the requirements for practical classes at the higher educational establishments and adapted to the communicative needs of foreign students who are studying in Ukraine. The structure of the lesson contains five stages: organizational part, mastering the lexical and grammatical material on the topic, performing training exercises, working with the text, current control. The content corresponds to the curriculum of the subject "Ukrainian as a foreign language", the task is created taking into account the program requirements and the purpose of the discipline in order to provide basic communicative needs of foreign students in everyday and educational spheres. The developed system of exercises is designed for the formation and development of various types of speech activity (listening, speaking, reading and writing). Knowledge of vocabulary to indicate the months and seasons of the year, learning ordinal numbers and the rules of their use in speech, the answer to the question WHEN? using the names of months and seasons, improving the skills of reading the text within the current topic allow to ensure the realization of communicative needs of foreign students in various fields of communication: everyday, social and cultural, official and business, educational and professional ones.

Key words: Ukrainian language as a foreign language, methodological guidance, knowledge, skills, communicative approach, tasks, months, seasons.

УДК 371.134:615.15:37.048,4

DOI https://doi.org/10.31392/NPU-nc.series5.2020.75.42

Філіппова Л. B.

\section{НОВІ ІНФОРМАЦЙНН ТЕХНОЛОГІЇ У ПРОЦЕСІ ВИВЧЕННЯ ХІМІЧНИХ ДИСЦИПЛІН МАЙБУТНІМИ ФАРМАЦЕВТАМИ}

Розглядаються вплив і переваги новітніх інформаційних технологій на вивчення хімічних дисциплін у медичних закладах. 3'ясовано, як можна організувати трансляцію від викладача до студента ефективніше, ніж шляхом простого читання лекиійного матеріалу. Використання новітніх сучасних технологій дозволяє студентові самостійно удосконалити та розширити свої знання. За допомогою комп'ютерних технологій студент здатний знайти відповіді на свої питання, які виникають під час вивчення певних тем. Завдяки новітнім технологіям надається можливість не лише спілкуватися з іншими студентами, а й обмінюватися науковими відкриттями. За допомогою технологій студент здатний розкрити свої творчі та пізнавальні здібності. Використання комп'ютерних технологій дає можливість забезпечити 